\title{
Exploring Student Perceptions of the Hidden Curriculum in Responsible Management Education
}

\author{
Høgdal, Catharina; Rasche, Andreas; Schoeneborn, Dennis; Scotti, Levinia
}

\author{
Document Version \\ Accepted author manuscript \\ Published in: \\ Journal of Business Ethics \\ DOI: \\ 10.1007/s10551-019-04221-9 \\ Publication date: \\ 2021 \\ License \\ Unspecified
}

Citation for published version (APA):

Høgdal, C., Rasche, A., Schoeneborn, D., \& Scotti, L. (2021). Exploring Student Perceptions of the Hidden Curriculum in Responsible Management Education. Journal of Business Ethics, 168(1), 173-193.

https://doi.org/10.1007/s10551-019-04221-9

Link to publication in CBS Research Portal

\section{General rights}

Copyright and moral rights for the publications made accessible in the public portal are retained by the authors and/or other copyright owners and it is a condition of accessing publications that users recognise and abide by the legal requirements associated with these rights.

\section{Take down policy}

If you believe that this document breaches copyright please contact us (research.lib@cbs.dk) providing details, and we will remove access to the work immediately and investigate your claim.

Download date: 26. Apr. 2023
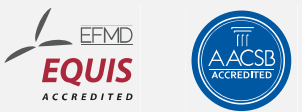


\title{
Exploring Student Perceptions of the Hidden Curriculum in Responsible Management Education \\ Catharina Hogdal, Andreas Rasche, Dennis Schoeneborn, and Levinia Scotti
}

\author{
Journal article (Accepted version*)
}

\section{Please cite this article as:}

Høgdal, C., Rasche, A., Schoeneborn, D., \& Scotti, L. (2019). Exploring Student Perceptions of the Hidden Curriculum in Responsible Management Education. Journal of Business Ethics.

https://doi.org/10.1007/s10551-019-04221-9

This is a post-peer-review, pre-copyedit version of an article published in Journal of Business Ethics. The final authenticated version is available online at:

DOl: https://doi.org/10.1007/s10551-019-04221-9

* This version of the article has been accepted for publication and undergone full peer review but has not been through the copyediting, typesetting, pagination and proofreading process, which may lead to differences between this version and the publisher's final version AKA Version of Record. 


\title{
Exploring Student Perceptions of the Hidden Curriculum in Responsible Management Education
}

\author{
Running Head: Hidden Curriculum \\ CATHARINA HØGDAL (catharina.hogdal@outlook.dk) \\ Copenhagen Business School \\ CBS Centre for Corporate Social Responsibility \\ Dalgas Have 15, 2000 Frederiksberg \\ Denmark
}

ANDREAS RASCHE (ar.msc@cbs.dk)

Copenhagen Business School

CBS Centre for Corporate Social Responsibility

Dalgas Have 15, 2000 Frederiksberg

Denmark

$\&$

Stockholm School of Economics

Mistra Centre for Sustainable Markets (MISUM)

Box 6501, 11383 Stockholm

Sweden

\author{
DENNIS SCHOENEBORN (ds.msc@cbs.dk) \\ Copenhagen Business School \\ Department of Management, Communication, and Society (MSC) \\ Dalgas Have 15, 2000 Frederiksberg \\ Denmark \\ $\&$ \\ Leuphana University Lüneburg \\ Institute of Management \& Organization (IMO) \\ Universitätsallee 1 \\ 21335 Lüneburg \\ Germany
}

LEVINIA SCOTTI (levinia@scottidesign.de)

Copenhagen Business School

CBS Centre for Corporate Social Responsibility

Dalgas Have 15, 2000 Frederiksberg

Denmark 


\title{
Exploring Student Perceptions of the Hidden Curriculum in Responsible Management Education
}

\begin{abstract}
This exploratory study analyzes the extent of alignment between the formal and hidden curricula in responsible management education (RME). Based on case study evidence of a school that has signed the United Nations Principles for Responsible Management Education (PRME), we found poor alignment between the school's explicit RME claims and students' lived experiences. While the formal curriculum signaled to students that RME was important, the school's hidden curriculum sent a number of tacit messages that led students to question the relevance and applicability of responsible management. The tacit messages that students received occurred along three "message sites" related to: (a) how the formal curriculum was delivered, (b) how students and lecturers interacted, and (c) how the school was governed. On the basis of these findings we develop a proposition that can guide further research in this area, i.e., that the connotative level of language use is an important site of misalignments between what lecturers say in relation to RME (e.g., in a syllabus) and how students interpret the meaning of their lecturers' words. We also discuss further implications of our findings for strengthening the alignment between schools' formal RME claims and their hidden curriculum.
\end{abstract}

\section{Keywords}

responsible management education, business education, hidden curriculum, PRME, classroom practices 


\section{INTRODUCTION}

As of April 2019, 767 business schools from more than 80 countries have signed up to the United Nations Principles for Responsible Management Education (PRME). By becoming a signatory, schools commit themselves to continuous advancement of responsible management education (RME). We use the term RME as a "descriptor for efforts aimed at embedding reflections about corporate responsibility (i.e., the social impact of businesses on society), environmental sustainability (i.e., the contribution of firms to a sustainable economy), and ethics (i.e., reflections about right and wrong in the context of business situations) into business schools' educational practices" (Rasche \& Gilbert, 2015, p. 240; see also Forray \& Leigh, 2012 and Laasch \& Conaway, 2015). A considerable body of literature has now been developed on the implementation of PRME in different business school contexts. Overall, this literature paints a mixed picture. While some studies find evidence that commitment to PRME can change RME practices despite the need to overcome barriers to implementation (see, for example: Maloni et al., 2012; Solitander et al., 2011; and Young \& Nagpal, 2013), other studies caution that commitment to these Principles may undercut critical reflexivity on the part of the faculty (Millar \& Price, 2018) or even end up as reputation management (Louw, 2015).

Although these studies have added critical insights, they mostly focus either on explicit information about a school's commitment to PRME (e.g., by analyzing progress reports: Alcaraz et al., 2011; Godemann et al., 2011, 2014) or information gathered through faculty members' experiences (e.g., Burchell et al., 2015; Solitander et al., 2011). Surprisingly little scholarly work has looked into how PRME has affected students' experience of RME. Even though a small number of PRME-related studies have focused on student experiences (HaskiLeventhal et al., 2017; Kirby, 2012), these works rarely consider the tacit messages that students receive in the context of RME (for an exception, with a focus on teaching materials, 
see Dever \& Mills, 2015). Based on studies of tacit knowledge (Cooper \& Sawaf, 1996; Polanyi, 1962), we understand tacit messages as those messages that escape actors' awareness and explicit articulation. For instance, teaching and assessment practices often convey tacit messages to students (e.g., about "what really matters") that escape the routinized perception of actors. This is why tacit messages have been found to be as powerful and influential in students' moral learning as explicit messages (Hafferty \& Franks, 1994).

Our study focuses on this tacit dimension of PRME implementation by empirically highlighting the role of the hidden curriculum (HC). The HC encompasses the socialization processes and informal learnings about norms and values that schools pass on to their students. Although the $\mathrm{HC}$ has been found to have a significant influence on students' moral learning (Hafferty \& Franks, 1994), it is rarely explicitly acknowledged in the RME context (for exceptions, see Blasco, 2012 and Borges et al., 2017). Getting the right RME message across to students is not only a matter of delivering formal curricular content but also of managing and aligning the HC's tacit messages with schools' more formal claims.

While Blasco’s (2012) work has highlighted the need to align schools' formal and hidden RME curricula, we still lack empirical insights as to whether and to what extent such alignment actually exists. Our exploratory study aims to contribute to this debate and therefore asks the following research question: To what extent are the formal and the hidden RME curriculum aligned within a business school participating as a PRME Champion? We explore this question through a case study of a European business school (hereafter: "The School"). As our research question implies, we assume that commitment to the PRME should ideally shape both a school's formal curriculum (Godemann et al., 2014) as well as its HC (Blasco, 2012). Overall, our data indicates that The School's formal and hidden RME curricula are not very well aligned. This misalignment was found to be driven by the occurrence of tacit messages along three HC messages sites: in the delivery of the formal curriculum, in interpersonal interactions, 
and in school governance. For instance, the formal curriculum was delivered in such a way that students developed the impression that CSR (and similar concepts) were mere 'buzzwords' and that CSR-related discussions are 'soft', non-theoretical and primarily grounded in common sense.

We make two contributions to the literature on PRME implementation. First, our study expands the literature that considers the tacit dimension of student experiences within PRME implementation (e.g., Borges et al., 2017). Our focus on the HC moves the discussion away from explicit communication and acknowledges that tacit messages also impact students' RME learning experiences (Blasco, 2012). Recognizing the role of these messages, we enrich the literature on decoupling related to RME (e.g., Snelson-Powell et al., 2016) by showing the relevance of an as yet unexplored proposition: the connotative level of language use (i.e. the tacit messages that students may interpret "between the lines") can drive misalignments between what actors say (e.g., in a syllabus) and how students interpret what actors mean. Second, we enrich the discussion about how schools can overcome barriers to PRME implementation (e.g., Solitander et al., 2011). We emphasize that (a) at institutional level there needs to be more explicit discussions of the role of $\mathrm{HC}$ by initiatives like PRME, as well as accreditation and ranking providers, and that (b) at organizational level business schools can undertake various activities to better understand and impact the $\mathrm{HC}$.

It is important to highlight the exploratory character of our study, at the same time. The alignment between formal and hidden RME curricula has not been studied extensively. While our study does not offer final or conclusive insights, we deliver indicative evidence of a previously neglected but important dimension of PRME implementation, i.e., the tacit messages related to RME and the interpretation of these messages by students. 


\section{THEORETICAL BACKGROUND}

We review the literature on two scholarly discourses relevant for our study: (1) works discussing how PRME is implemented, and (2) research concerned with the HC in higher education in general and in RME in particular.

\section{Implementing the Principles for Responsible Management Education}

The literature on PRME implementation is diverse and cuts across multiple perspectives, including case studies on individual schools as well as surveys of students and faculty. One common thread that runs through this literature is the acknowledgement that "just signing" (Fougére et al., 2014, p. 186) PRME is not necessarily indicative of change. Whether and to what extent the Principles are addressed depends on local implementation efforts, which in turn are shaped by enablers and barriers that are deeply embedded in an organization's context and history (Young \& Nagpal, 2013; Solitander et al., 2011).

Some studies have adopted a macro perspective, seeking to provide an overview of implementation efforts by reviewing the activities that different signatory schools have launched under the PRME umbrella. Alcaraz et al.'s (2011) analysis of Sharing Information on Progress (SIP) reports showed that schools refer to a variety of activities to implement the six Principles. While this diversity shows that implementation is local and that different contexts call for different solutions, it also indicates there may be too much flexibility for participants, meaning that results can barely be compared (see also Burchell et al., 2015). Godemann et al.'s $(2011,2014)$ analysis of SIP reports revealed a similar picture but also emphasized that most schools focused on teaching-related aspects, for instance by developing new programs and courses or by rethinking traditional teaching methods. By contrast, comparatively few schools employed tools to reflect on their own RME practices (e.g., in order to address implementation barriers). 
A number of studies have discussed PRME implementation in the context of single institutions (Cicmil et al., 2017; Escudero et al., 2017; Fougére et al., 2014; Greenberg et al., 2017; Kolb et al., 2017; Nhamo \& Nhamo, 2014; Solitander et al., 2011; Warin \& Beddewela, 2016; Young \& Nagpal, 2013). Solitander et al. (2011) reported how implementation was organized in two PRME signatory schools in France and Finland. They emphasized the need to overcome strategic barriers (e.g., short-term goals), structural barriers (e.g., departments competing for resources), and cultural impediments (e.g., the view that RME is irrelevant). Scholars have also shown how PRME implementation can challenge the dominant vocabulary used within business education (e.g., the centrality of shareholders; Fougére et al., 2014). Young and Nagpal's (2013) study of an Australian higher education institution stressed the need to view PRME implementation as a top-down and bottom-up process that needs to overcome a number of barriers (e.g., resistance to change). Greenberg et al.'s study (2017) revealed that while Babson College embarked upon a process of curricular and pedagogical change, this change process resulted in only a limited impact on student learning.

A number of studies have investigated PRME implementation through student or faculty surveys (see e.g., Kirby, 2012). Haski-Leventhal et al. (2017) focused on student perceptions by surveying PRME-signatory schools with a focus on how various sub-groups of students perceive RME. The authors found support for the hypothesis that female students were more welcoming to curriculum changes than male students, though their study could not support the hypothesis that older students were more interested than younger students in increasing RME content. Maloni et al.'s (2012) survey of faculty support for PRME implementation in a US institution painted a mixed picture. On the one hand they found that the general faculty environment was supportive of PRME-related aspects (e.g., faculty valued sustainability knowledge). On the other hand, faculty lacked interest in teaching or researching topics such as responsibility and sustainability. 
There is also a stream of research that has looked at PRME implementation more critically. Some scholars have voiced concerns that PRME signatory schools may not walk their talk, for instance because schools may face covert or even open resistance to change processes (Rasche et al., 2013; Rasche \& Gilbert, 2015). Burchell et al.'s (2015) study partly confirmed this finding. For while their research showed that PRME signatory schools increased the number of elective courses with RME content, it also questioned whether PRME itself acted as a catalyst for such changes. The study emphasized that discussing the impact of PRME "may be far more complex to evaluate than in simple terms of direct curriculum change" (Burchell et al., 2015, p. 495). We believe this finding shows the relevance of studying the HC.

Other critical studies have focused more directly on the role of faculty. Cezarino (2016) surveyed professors about their opinions on RME in general and PRME in particular. While most professors agreed on the general importance of this area, they evinced a low level of familiarity with PRME objectives. Millar and Price's (2018) study showed that PRME implementation did not foster critical reflexivity among faculty within a UK business school. They emphasized that PRME acted as a filter of meanings and thereby discouraged critical reflexivity (instead of promoting it), concluding that resistance to PRME (e.g. by mobilizing alternative discourses) may actually create more space for rethinking management education than the adoption of PRME itself. Louw's (2015) analysis of SIP reports from UK business schools painted a similar picture, arguing that PRME presupposes a rather unproblematic understanding of management education, especially insofar as business schools are portrayed as servants of corporations and SIP reporting has a strong focus on reputation management.

While much has been written about PRME implementation, little work has focused directly on the HC. Although some of the studies reviewed above do discuss aspects relevant to the HC (e.g., Rasche et al., 2013 highlight the largely elective status of RME-related courses and the tacit message this sends), the concept of $\mathrm{HC}$ as a whole has rarely been examined in 
the context of PRME. One exception is Blasco's (2012) conceptual article, which argued that the HC influences the meta-messages that students receive. Such messages define what students view as appropriate conduct and influence how students perceive "what really matters" (Blasco, 2012, p. 380). Another exception is Borges et al.'s (2017) analysis of student organizations, which argued that such organizations generate learning content that is not addressed in the formal curriculum. Students often create their own learning content through such organizations because the formal curriculum does not address RME sufficiently. Dever and Mills' (2015) analysis of leadership chapters in textbooks on Organizational Behavior also relates to the HC. They showed that the underlying themes discussed in textbooks were still mostly masculine in nature and thereby send tacit messages to students. Although this literature has helped us better understand the general relevance of the HC for PRME implementation, it has not yet delivered empirical insights into whether and to what extent the formal and hidden RME curricula are aligned. Our study attempts to offer some initial exploratory insights in this direction.

\section{The Hidden Curriculum in Higher Education}

Many scholars contrast the HC with the formal curriculum (Hafferty \& Franks, 1994), viewing the HC as encompassing "implicit education" (Bergenhenegouwen, 1987) and socialization processes (Margolis et al., 2001). We follow these notions and understand the HC as comprising "what is implicit and embedded in educational experiences in contrast with the formal statements about curricula and the surface features of educational interaction" (Sambell \& McDowell, 1998, pp. 391-392). This definition stresses the importance of experience, which is key to our study with its focus on student perspectives. The HC is not hidden in the sense that it cannot be observed (Gair \& Mullins, 2001; Tonso, 2001). What is hidden refers to what is usually unnoticeable because it escapes our routinized perspectives of what happens inside 
and outside the classroom. Blasco (2012, p. 368) therefore argues that the HC is hiding in plain sight and that it "might more accurately be thought of as a backdrop that school actors learn to 'not-notice'."

A number of studies have discussed the $\mathrm{HC}$ in higher education (e.g., Bergenhenegouwen, 1987; Hafferty \& Franks, 1994; Trevino \& McCabe, 1994; Sambell \& McDowell, 1998), while only a few studies have researched the HC in the business school context (Blasco, 2012; Ehrensal, 2001; Ottewill et al., 2005; Orón Semper \& Blasco, 2018). Among these scholars, Blasco (2012) is the only one who has operationalized the concept of the $\mathrm{HC}$ in the context of RME. Her framework is based on Hafferty and Franks' (1994) description of the school as a multi-dimensional learning environment, and she identifies three message sites where the HC operates: (1) the formal curriculum, (2) interpersonal interactions, and (3) school governance. Students pick up the HC in these three sites through messages that implicitly define what is valued by the organization.

Formal curriculum. The formal curriculum may seem a puzzling place for students to pick up the $\mathrm{HC}$, since scholars tend to describe the $\mathrm{HC}$ in contradistinction to the formal curriculum; however, it is not the explicit messages of the formal curriculum that Blasco (2012) is concerned with but rather the tacit messages related to the delivery of the formal curriculum (e.g., classroom and assessment practices). These practices can send subtle messages to students about which learnings are valued. For instance, students often have an instructororiented attitude, meaning their study behavior is influenced by what the instructor finds relevant (Bergenhenegouwen, 1987). Critical scholars have shown how different forms of authority come to be accepted as legitimate by students (e.g., Ehrensal, 2001), including the roles of professors and textbooks in this process. Professors appear to convey objective, factual knowledge due to their expert status and usage of a seemingly agreed upon business language which in itself carries legitimacy. Formal education in classrooms never takes place in a value- 
free environment, since norms, values and belief systems are deeply embedded in the formal curriculum (Margolis et al., 2001).

Interpersonal interactions. Through personal interactions, both within and beyond the classroom, students are socialized into one or more groups wherein the degree of belonging depends on students' alignment with the group's dominant norms. Participation in the group may "work as a centrifugal force" (Blasco, 2012, p. 372), meaning that students, whose norms are not aligned with the group, are likely either to adapt or leave. It thus seems appropriate to assume that influential socialization processes take place within study programs among classmates. Other actors such as administrators, faculty, and student organizations may be equally important in sending tacit messages. Many of these actors carry the authority of the school and therefore the tacit messages they send can have an impact on students. Anecdotes, stories, jokes and stereotypes can therefore help to reveal the HC (Blasco, 2012).

School governance. The term "governance" is used in a rather broad sense here and refers for our purposes to whether schools practice what they preach (Blasco, 2012). For instance, a school that emphasizes RME should reflect on its own social and environmental practices. School governance also encompasses the physical structure of the school, such as the lecture halls, buildings and the larger campus area. Gair and Mullins (2001) found that the physical environment plays an important role in marginalizing some disciplines and favoring others (e.g., when assigning "good" lecture halls to certain programs). The physical environment also matters because corporate sponsorship of lecture halls can send signals to students. Corporate logos can be interpreted as endorsements of corporations, which is especially controversial in the case of corporations with a history of irresponsible behavior. 


\section{METHODOLOGY}

\section{Case Selection}

The School is a large organization with several thousand students and several hundred fulltime academic staff. It was selected as being one of the acknowledged PRME frontrunners. Having been among the early adopters of PRME, RME has been on The School's agenda for almost a decade now. This is important because the extent of alignment between formal and hidden curricula can best be studied in schools where relevant actors have had sufficient time to implement RME. Following its formal commitment to the PRME, The School established an Office of Responsible Management Education (also known as the "PRME Office"). Having a dedicated PRME Office is noteworthy since this is rare among signatories. The PRME Office consists of one Academic Director, three core staff and more than ten part-time support staff (mostly student assistants). The existence of this Office sends a signal about senior management's commitment to implementing PRME. In 2010 The School launched its new strategy, which included a strong focus on RME and its implementation within all study programs. In 2013, the UN appointed The School as one of 29 "PRME Champions" recognized as leaders and examples of best practice in implementing PRME.

\section{Data Collection}

Because The School is a large organization with more than 20 Bachelor and 20 Master programs, data collection had to be limited to selected programs via "purposeful sampling" (Charmaz, 2006; Glaser \& Strauss, 1967). We gathered data on five Bachelor programs and two Master programs (see Table 1). These seven programs were chosen because they balance programs with a stronger quantitative focus (one Master and two Bachelor programs) with programs that put less emphasis on quantitative techniques (one Master and three Bachelor 
programs). By mixing Bachelor and Master programs we further ensured that we covered the variety of programs at different levels of experience.

Our findings were generated from the triangulation of three data sources: (1) focus group interviews (including free writing sessions), (2) participant observations, and (3) an analysis of documents on RME produced by The School. We deemed data triangulation to be necessary since it may not always be possible for students to recollect the HC's tacit messages in an interview (e.g., because relevant practices have become a natural part of the school; Blasco, 2012). Participant observation of students' actions and expressed beliefs in everyday situations was therefore important (see also Tonso, 2001). Data collection took place in two waves, in 2016 and 2018, i.e., almost ten years after The School initially signed up to PRME.

Insert Table 1 About Here

Focus group interviews. Focus group interviews with students were a useful way to generate knowledge about which tacit messages they pick up at which different sites. We developed an interview guide (see Appendix 1) inspired by Blasco's (2012) inquiry-based framework. The interview guide format (Patton, 2015) used for the focus groups allowed us to uncover critical areas of interest while remaining open to pursue new and unanticipated themes the students brought up themselves (Kvale, 2011). The interview guide format was especially suited for conducting interviews in focus groups as it kept "the interactions focused while allowing individual perspectives and experiences to emerge" (Patton 2015, p. 439). We aimed at facilitating a conversation that felt natural to the students, with the moderator only occasionally participating in the dialogue (usually with "why" or "how" questions). The moderator was also careful not to nudge students in any particular direction. In total we held 14 small focus groups with two to four students each, resulting in a total of 32 participants (12 
male and 20 female; see Table 1). Random sampling was used to identify students from the different study programs for the focus groups.

The small focus group format was adopted because we needed detailed reflections on students' experiences of the $\mathrm{HC}$ and the small group size enabled such detailed reflections (Toner, 2009) while at the same time allowing for discussions among students. Each focus group lasted 40-60 minutes. We mostly conducted focus groups with students from a single study program in order to create a "safe space" in which students could freely share their impressions of other study programs, since such impressions reflect an important part of the HC (Blasco, 2012). Although one group of students from mixed programs was created to crosscheck whether different group dynamics would reveal new discussion points, this group yielded findings largely in line with the single-program focus groups. The focus groups related to the two Master programs only included students who had also studied their Bachelor program at The School, since they were more likely to have been influenced by The School's HC over time. At the beginning of each focus group the participants were asked to "free write" on four key terms: (1) The School, (2) their own study program, (3) other study programs, and (4) CSR / RME. Our main aim was to find out which themes or experiences came to mind first when students thought about these terms (e.g., whether topics related to RME appeared when thinking about their program). After this exercise we gave students a quick briefing about the purpose and procedure of the task.

Participant observations. One of the authors, who was herself a master student at the time, followed classroom practices as a participant observer. Since most students are unlikely to be aware of the HC (Tonso, 2001), participant observation seemed to be an effective way to reveal blind spots. The author thus participated in lectures where she could access students' everyday practices based on classroom interactions, sitting with at least one student at each lecture who had agreed to let her ask questions and who also knew about the purpose of her 
presence - a technique also successfully applied by Tonso (2001). The observations allowed us to discern aspects of the HC that had not come up during focus groups and so enabled us to better direct questions during future focus group discussions. Lecturers were not made aware of the presence of the observing author since it was crucial for our study focus that instructors did not feel observed and thus potentially change their teaching practices in response - a covert mode of observation we argue is justifiable for the purpose of tracing the tacit side of the $\mathrm{HC}$ (for a similar argument, see Li, 2008). Our findings are presented in aggregate to ensure they cannot be traced to any particular lecturer.

The participating author wrote field notes based on what she had experienced and on what the students she talked to had said. In total our focus group data was enriched by eight observations of lectures. During these observations the participating author gathered insights through informal ad-hoc conversations with an additional 15 students ( 8 male and 7 female). In this method we were guided by the argument made by Guest, Namey, and Mitchell (2013, p. 84) that "informal interviews are almost always part of participant observation". These informal conversations did not follow a standardized interview guide; rather, questions emerged ad-hoc and in close relation to the content of the session jointly experienced with the students (see also Kvale, 2008, p. 148), allowing us to ensure the informal interview approximated natural conversation. We further made sure to ask open questions primarily aimed at triggering narrations on the part of the interviewees.

Documents. We also included several secondary data sources in the analysis, mostly in the form of documents related to The School's engagement in RME. First, we analyzed all of The School's mandatory PRME “Sharing Information on Progress” (SIP) reports (available for the years 2010, 2013, 2015, and 2017), which take stock of key achievements related to RME and outline relevant aspirations and policies. Second, we analyzed the results of The School's own Curriculum Development Project aimed at reviewing all Bachelor programs and identify 
which courses included RME content. The School's Curriculum Development Project is currently being expanded to include all Master programs, the results of which are not yet available. Finally, we added relevant press releases to the dataset (e.g., when policies or achievements related to RME/PRME were communicated).

\section{Data Analysis}

The data analysis was based on the transcribed interviews and field notes. We followed an iterative process, constantly moving between the collected data and the analysis of this data (Charmaz, 2006). Through coding, dominant themes emerged that sensitized further inquiry and developed into key categories. The benefit of engaging in this iterative process was that it helped us to adjust the methods when themes emerged that appeared relevant for further investigation. For instance, in the course of our interviews it became clear to us that a bank's sponsorship of The School (see below) was a dominant theme and we therefore decided to pursue this theme further.

Our data analysis does not follow a pure-play inductive approach, as grounded theory would traditionally suggest (Glaser \& Strauss, 1967). Instead, our coding procedure was also informed by our theoretical pre-understanding of key concepts, such as the message sites attached to the HC. It is thus more appropriate to classify our research strategy as abductive in character since it involved back-and-forth movements between theoretical concepts and our empirical material (Ketokivi \& Mantere, 2010). More specifically, this strategy involved a three-step procedure. First, when going through the data we assigned first-level codes to themes addressed by the interviewees. This initial coding relied on "in-vivo codes" (Charmaz, 2006, p. 55) in order to stay close to the terminology used by the interviewees. In the second step we attained a higher level of abstraction by adding second-level codes that allowed us to subsume various first-level codes under one dominant theme. For instance, themes like "CSR as a buzzword" or "CSR as non-integrated topic" emerged from our data in this way. This second 
step involved various rounds of regrouping and analytical sharpening of the codes in relation to one another. The third step then added the abductive element by cross-checking the extent to which the dominant themes were related to the message sites discussed by Blasco (2012). The three key categories (formal curriculum, interpersonal interactions, and school governance) were related to several dominant themes in this way. Appendix 2 provides an overview of our data structure.

\section{Limitations}

Our study has several limitations that we would like to mention prior to presenting the study's main findings. First, our results are based on an analysis of seven study programs within one European business school. Although we found robust patterns across the analyzed programs, our results should not be interpreted as definite and conclusive evidence regarding the $\mathrm{HC}$ in the context of RME. For instance, we can assume different results will be obtained when studying programs that have CSR and sustainability as their main study focus. As indicated above, we view our study as explorative in nature. Second, there is a likelihood that selfselection bias has influenced the results, that is, students with specific values select themselves into particular programs (Arieli et al., 2016). We tried to overcome this bias by maximizing the variety of study programs analyzed. Third, while the small focus group format served the purpose of our study and ensured the level of intimacy needed for students to speak openly, it is also clear that the limited size reduced the potential scope of the discussion in some cases. Finally, while we had access to documents related to The School's Curriculum Development Project for all Bachelor programs, we did not have comparable data for the two Master programs. We have therefore analyzed the formal RME curricula attached to the two Master programs by examining the relevant course syllabi. 


\section{FINDINGS RELATED TO THE FORMAL CURRICULUM}

Given that we are interested in studying in how far the formal and hidden curricula are aligned, we first need to unpack The School's formal RME curriculum. This unpacking relates both to (a) the formal RME content across all study programs at The School and (b) to the formal RME content within the seven study programs analyzed for this study.

\section{RME Content Across All Study Programs}

In 2015, The School's president said in a public statement that RME is already an implicit part of all The School's degree programs. Although the directors of individual programs are asked to develop their own perspectives as to the precise meaning of RME in their respective contexts, it is clear The School requires all programs to reflect on relevant content and competencies. The School also communicates through its leadership team that RME is taken seriously across all study programs and that related content is integrated in the formal curriculum. Practically speaking, one initiative to embed RME into all study programs is the discussion of relevant topics during the Introduction Week. Since 2009, all new Bachelor students are given an introduction to RME during their first few days at The School. According to The School's SIP report, the aim is to provide students with an opportunity to reflect on dilemmas of business ethics and CSR. Students are thus exposed to a number of keynote talks as well as a case competition focused on a topic relevant to RME. Interestingly, some students perceived this attempt to mobilize the entire school around RME as "superficial PR" (BA INT focus group). 


\section{RME Content Within Specific Study Programs}

Table 2 gives an overview of RME content in the formal curriculum of the study programs included in our research. The data for the five Bachelor programs is based on The School's Curriculum Development Project that analyzed in detail the formal curriculum of each study program vis-à-vis RME content. The data distinguishes between Flagship Courses (i.e., those courses that play a central role in developing responsible management competencies) and Cornerstone Courses (i.e., those courses that represent connecting points between semesters and ensure the systematic advancement of competencies related to responsible management).

Insert Table 2 About Here

The picture that emerges is rather consistent. Although depth of RME content differs across study programs, students in all the programs considered are exposed to relevant debates at some point. BA ECON and MA E\&F stood out as programs with relatively little RME content, while the other four Bachelor programs and MA COM had significant levels of RME content. Table 2 also lists the desired competency profile related to RME for each program. This information was again provided through the Curriculum Development Project and is based on discussions within the programs' respective study boards. Again the picture that emerges is rather consistent. All study programs aim at integrating RME debates within the competency profile that underlies the course portfolio. It is therefore fair to conclude that the selected programs attempt to anchor RME content throughout the formal curriculum, even though there are differences in terms of the level of integration. While the formal curriculum can tell us whether RME content is present, however, it is the $\mathrm{HC}$ that can reveal how students experience such content and what kind of signals they believe they receive. 


\section{FINDINGS RELATED TO THE HIDDEN CURRICULUM}

Our findings are structured along the three HC message sites. Empirically speaking, tacit messages picked up in one site were often reinforced by messages picked up in the other two sites, hence the three sites need to be seen as interacting with each other. We describe RME mostly through the "CSR" label throughout our discussion, as this was the term most often used by the students during their reflections. Table 3 summarizes the tacit messages.

Insert Table 3 About Here

\section{The Formal Curriculum as an HC Message Site}

CSR as a buzzword. Students pointed out that in their perception discussions around concepts like CSR, sustainability and ethics remained superficial. As one student said, "CSR appeared as this superficial buzzword you didn't know what to do about [...] it was mentioned over and over again, but we didn't really go into depth" (MA COM focus group). This view was echoed by other students, and at least one student within every focus group used the term "buzzword" to describe how they had experienced RME. One student, for example, declared "I think it [CSR] is kind of a buzzword. So it's trendy, but I don't know how trendy it really is anymore" (MA COM focus group). The term "buzzword" stood out as an emic category across all focus groups. Even students who did not explicitly use the term "buzzword" used similar descriptions (e.g., "posh word", BA INT focus group) indicating they found CSR to be a rather superficial concept without much meaning. One student (MA COM focus group) explained that "[i]t was presented like CSR wasn't very useful, because teachers touched upon it so superficially”.

A number of students also perceived RME as being primarily a matter of mere common sense, i.e. as something everybody knows about anyway without having to study it, in some case declaring they did not need to learn about responsible management at university since they 
could always just talk their way around the subject. One student said "I have a feeling that I don't need a course on it [CSR] to learn about it [...]. I mean I don't need to learn that a tenyear old boy doesn't belong on a tobacco farm" (MA E\&F focus group). This student believed that CSR theory was unnecessary, either in university education or in organizational practice, since everyone could just use their common sense and act responsibly. Another student said "[...] there is too much discussion about CSR, where I think 'Any idiot knows that!'." (BA COM1 focus group).

Students emphasized their perception of RME-related topics as rather shallow and nontheoretical in character. One student noted that "Every time we were presented with a CSR problem it was like you couldn't really do anything about it. We didn't have theoretical frameworks to grab on to" (MA COM focus group). Students expressed concern that CSR discussions degenerated into "an opinion-based matter" (MA COM focus group). As a consequence, many doubted the relevance of RME. One student said "The thing is, for me, responsible management education is, as I said, really highly important, but if you are not making the education practical, how can you actually use this? What are the benefits of it?" (BA INT focus group).

CSR as a non-compulsory reading and exam topic. Students pointed out that their assigned readings also shaped their perspectives on RME, with many reporting that RMErelated debates had never been a prevalent theme in their assigned readings. As one student explained, "I remember during the Bachelor, CSR was always a chapter in the back of our books. But it never really felt like it was part of the courses" (MA COM \& MA E\&F focus group). If CSR is always just a chapter at the back of a book that is not addressed or integrated in the course, this sends a signal to students about the topic's lack of relevance, especially as textbooks tend to enjoy legitimacy and authority (Ehrensal, 2001). 
Two students revealed they would often skip the CSR parts of their reading assignments because they would never be caught off guard in exams for not having read up on this topic (MA COM focus group). It emerged that exams have a significant influence on the students' reading strategies and perceptions of which topics ultimately mattered. This also became evident during the participant observations, where questions about exams came up in almost every lecture. Because students did not think CSR would be included in their exams they would not spend time reading up on it. Not including CSR as a theme in exams (on a level that demands preparation) sends a signal to the students that it is not a topic to which they need to pay much attention. This further reinforces the perception among students that mastering "softer" topics like CSR does not require the same efforts as mastering "harder" topics like finance and accounting.

CSR as a non-integrated topic with doubtful practical relevance and applicability. Several students highlighted that RME had no relevance to some of the "harder" subjects like finance and accounting. In one lecture on investment and risk, the author leading the participant observation asked a student how he understood the concept of "risk", to which the student's response revealed an understanding limited solely to monetary meaning with no reference to social or environmental dimensions (E\&F observation). The student's narrow understanding of risk was influenced by how the lecturer explained and applied the term, as the student later explained himself: "I think the teacher just teaches us the financial tools. He does not teach us about values or opinions" (E\&F observation). In another lecture, the instructor addressed the question of what value creation means, emphasizing that all projects in a company should create shareholder value, with the main goal being to optimize profits. When the author leading the participant observation subsequently asked one student how he understood "value creation", their response almost exactly mirrored the lecturer's words (E\&F observation). 
Overall, students emphasized that while most programs have some sort of RME-related content there was a lack of integration of relevant debates throughout the curriculum. One student declared that "I do not feel that it is something we really learn in the study [program]. I mean we learn about CSR - this is more common - but it is not so much in relation to the individual subject or study program" (BA COM1 focus group). Another student said "We are being taught some core theories, and then, on the side, sort of detached from the core functions of the corporations, we learn about CSR" (MA COM focus group). This perception was echoed by most students, with the unfortunate consequence that "No one really understood how to integrate it [CSR] into decisions and business models" (MA COM focus group). This general lack of integration led students to believe that RME content was an "add-on" to their studies. One student emphasized: "It's like when you know the basic things about the other topics, you can add CSR as something extra. We have to know how to make a good marketing report, and then we can add some CSR if necessary, but it's not like a very important topic" (BA COM2 focus group). Treating RME debates as an "add on" throughout the curriculum led students to believe that CSR is also an "add on" in corporate practice. As one student pointed out, "CSR usually involves spending money on things that aren't really helping maximize profits. It's not really part of the core business" (MIXED focus group).

\section{Interpersonal Interactions as an HC Message Site}

Lecturer-student interactions. Lecturers can influence learning not only through the design and delivery of the formal curriculum but also through their language of socialization (e.g., in their use of examples, metaphors, success stories, cautionary tales; see Blasco, 2012). Our data shows that at least some lecturers practiced differentiated treatment according to different study programs. For instance, one of the Master programs analyzed for this research (MA E\&F) has an elite reputation at The School and students must come from Bachelor programs that demand 
a very high GPA to be accepted. This has not gone unnoticed by lecturers. Starting off the year, one economics and finance $(\mathrm{E} \& \mathrm{~F})$ student told us that a lecturer welcomed the class by saying: "So you guys are the smartest people in [the country where The School is located]" (MA E\&F focus group). Being perceived as smart, high-achieving and at the top of the class is important to E\&F students' group identity. As an unfortunate consequence, E\&F students did not ask questions during class when they did not understand something because "people just did not want to seem stupid" (MA E\&F focus group). However, critical reflection and questioning are vital to foster transformational learning and to challenge business-as-usual thinking (Blasco, 2012), both of which are key to RME in general and to PRME in particular.

While lecturers socialized E\&F students into competition and ambition for grades and prestige, at least some lecturers on other programs did the opposite. In the free writing exercise, one non-E\&F student wrote that the lecturers are not very ambitious (MA COM focus group). During the focus group, the same student related an incident in an economics class where the lecturer had introduced the class with the statement: "We're doing the easy version so it's not too difficult for you" (MA COM focus group). Another student shared similar experiences when telling us about her thesis defense, noting that the supervisor had told her "the work on the analysis was pretty weak, but that was probably because she studied MA COM. He was like 'What can you expect?'” (MA COM focus group). As authority figures, lecturers have an influence on which norms and values are perceived as important among students (Pace \& Hemmings, 2007), and our findings confirm the relevance of the tacit messages sent by lecturers vis-à-vis RME.

Students also expressed doubt as to whether lecturers have the relevant practical knowledge to teach RME-related topics. One student emphasized: "they [the lecturers] learn all these theories and then they go on and have their masters and more theories, and then they have their $\mathrm{PhD}$ and a project on these theories. And then they teach these theories again. And 
then you don't get this real life 'how-to-be-an-actual-responsible-manager'. Because they don't know" (BA SOC focus group). Similar concerns were expressed in relation to $\mathrm{PhD}$ students who sometimes teach RME-related topics: "Yeah the problem, maybe challenge, with PhD students teaching is that they don't have any real-world experiences" (BA SOC focus group). These statements show the importance of selecting lecturers so as to ensure RME is not devalued in the eyes of the students.

Student-student interactions. Our data shows that it is important to have an eye both for socialization processes (a) between students from different study programs and (b) among students from the same program (e.g., Elkin, 1995; Sambell \& McDowell, 1998). In socialization processes between students from different programs, stereotyping acts as a driver that distinguishes students. In socialization processes within a study program, the group's norms, values and practices become a centrifugal force driving participation and selfperception (Blasco, 2012). The students from the E\&F Master program are met with high expectations from day one and are continually exposed to opportunities (e.g., case competitions) to make themselves stand out. Three students discussed this during one of the focus groups, with one student opening the discussion by saying "I don't think we really compare ourselves to the other programs," while another added: "Everyone looks at each other. So it just becomes part of the student culture to be ambitious and hard-working. I think we sort of motivate or pressure each other. People who work harder than you make you want to do better" (MA E\&F).

Getting the most prestigious job with the highest salary after graduation is what matters most and what drives participation in school and extracurricular activities. CSR is not a concern these students are focused on because they do not see this particular topic as helping them achieve the success they strive for. As one student put it: "I think that most of my friends on [the program] are pretty indifferent to CSR. They want to be investment bankers, so to them 
it's numbers and profit optimization that count and not child labor in Africa" (MA E\&F focus group). CSR is not perceived as core to E\&F students' socialization processes or their ambitions and aspirations, hence there is no motivation to pursue relevant practices. One student summed it up: “Society doesn't see CSR as prestigious or as a high-achieving thing. And these guys [his fellow classmates] claim to be high-achievers. A CSR manager is just not as prestigious as an investment banker. Are you in the top two percent or not? And CSR managers, at the moment, are not" (MA E\&F focus group).

Overall there was agreement among students from "softer" programs (i.e. programs which did not emphasize finance and economics) that their programs were considered less prestigious. Students based this view partly on the stereotypes they encountered from other students. For instance, E\&F students believed they had the "harder program" (MA E\&F) compared to other students. The HC carried the tacit message that "softer" study programs do not have the same value in the business world as "harder" programs. And because students perceived RME as belonging primarily to the "softer" programs, the same tacit message seems to be tied to CSR and related topics. During the focus groups one student explicitly made this connection, saying that CSR "is viewed as a soft area [...]. And at [The School] that means it is looked down upon" (MA COM focus group).

\section{School Governance as an HC Message Site}

Corporate sponsorships. One aspect that received attention from students was the structuring of The School's physical environment. Some students thought it unethical of The School to let corporations with questionable pasts/reputations sponsor lecture halls and have their logos on display. One student expressed the view that "[i]t feels like [The School] values big corporations with power and money more than anything, and that it is their interests we should serve. It seems a little bit contradictory that they sponsor the halls where we have ethics classes" 
(MA COM focus group). Another student emphasized: "I think it sends mixed messages, regardless of whether or not it affects lectures or if the corporations get favorable treatment. The logo outside the lecture halls will always indicate that [The School] is approving of that company or wants to be associated with it. So in that way I think [The School] is sending mixed messages, if they want to be perceived as responsible" (MA E\&F focus group). Students' discussed two examples in particular, the first of which relates to a tobacco firm that was until recently one of The School's corporate sponsors. One student (BA INT focus group) discussed The School's handling of the case: "I think it has been quite reactive so far. Because they had all these collaborations, let's say with the [tobacco firm], where they only reacted when people started to ask 'Hey, why are you collaborating with them?' and then ended the partnership."

The second example relates to a bank that was recently involved in a scandal, in reaction to which The School announced it would not establish new collaborations with the company. Several students expressed their satisfaction with this decision, showing that consistency between The School's emphasis on RME and its own organizational practices is appreciated. One student (BA COM1 focus group) said: "We had a case day, where [the bank was] supposed to be there. But [The School] has cut off all contact with [that bank]. So that really started some thoughts in my head, that they really actually do care about their image and they don't want to be associated with it." Another student related the case directly to The School's moral agency: "I think it shows some moral that they take a stance in the [bank] case [...]" (BA COM1 focus group).

Hiring practices. Another theme related to school governance emerged as students discussed The School's hiring practices. Most of the discussion was related to the employment of a former investment banker by the Department of Finance at The School. The former banker had been prosecuted for defrauding investors in a derivative deal linked to subprime mortgages. After his time at Wall Street, he pursued a $\mathrm{PhD}$ in economics. Students expressed concern that 
this controversial hiring coincided with the scandal surrounding the bank (see above). One student. for example, said "I heard that [The School] had hired someone from [Wall Street], with the financial crisis and all that stuff. And I was like: ok you stop collaborating with [the bank] because they did something bad, but then at the same time you hire this person who also did something bad. So I'm like: what is the point?" (BA ECON focus group).

Some students expressed hope that the new academic would use teaching as an opportunity to reflect critically on his past. As one student put it, "if he is able to be a professor and if he likes to talk about mistakes [...] and likes to incorporate that in his lectures and his studies, that would be a great opportunity" (BA COM1). However, the majority of students were skeptical about the former banker's employment. One student emphasized that "there is a lot of risk, because he has that kind of background" (BA COM1 focus group). As with corporate sponsorships, some students also pointed out the mixed messages being sent about RME. One student discussed the incident as follows: "[The School] just said, 'Well, we think that what somebody did 10 years ago, shouldn't influence the rest of their lives.' But I think if you really want to have a good CSR strategy and be responsible, you have to be like full-blown, completely $100 \%$, really think about everything you do, rather than just doing something here something there. And maybe try and create some positive image. Because then again it is just about having a positive image, rather than doing something that actually matters" (BA INT focus group).

\section{DISCUSSION}

The formal and the hidden RME curricula were not well aligned in our case study organization. The three message sites included tacit messages that diverged from formal policies and aspirations to implement the PRME. While we should not rush to conclusions based on evidence from a single case study, we nevertheless believe our study adds to the existing PRME 
literature in two ways. First, our exploratory results show the relevance of further debating the decoupling of RME (e.g., Snelson-Powell et al., 2016) and the need to include the connotative level of language in future research. Second, our results enrich the debate about how schools can better align their formal and hidden RME curricula (e.g., Borges et al., 2017).

\section{Connotative Decoupling in Responsible Management Education}

Our findings are relevant for the literature on policy-practice decoupling in RME (e.g., Rasche \& Gilbert, 2015). Relevant research in this area is currently concerned with the extent to which the formal RME curriculum is integrated in classroom practices. Our study complements this literature by offering exploratory insights into a new aspect: even if the formal RME curriculum has found its way into classroom education (and thus would not constitute policy-practice decoupling as such), our study reveals that misalignments can still occur on a different level. This new angle on RME decoupling rests on our observation that misalignments may also be based on the connotative use of language (i.e. the hidden messages and wider meaning associations that audiences interpret "between the lines"). In our study, the uncovered tacit messages signaled a low value placed on topics like CSR, which in turn undermined the value of RME in the eyes of students. Although our data should not be interpreted as showing comprehensive evidence for such connotative decoupling, our research yields indicative evidence for the existence of such decoupling.

This focus on the connotative dimension of decoupling also corresponds with the work of Li (2017), who has stressed the distinction between the denotative and the connotative dimension of language use in institutional theory. Emphasizing the possibility of connotative decoupling implies that misalignments not only occur between what actors say they will do (e.g., in a syllabus) and what they actually do (e.g., in a classroom), which has been emphasized by existing policy-practice decoupling discussions within the RME literature, but also between 
what actors say (e.g., in a syllabus) and what others interpret them to mean (e.g., tacit messages as interpreted by students). For instance, a lecturer may emphasize topics like sustainability and CSR throughout the syllabus but then overlook these topics when it comes to the exam. Students, in turn, may perceive this as a signal of the topics being irrelevant. Our study highlights how the way in which RME is institutionalized in practice depends primarily on the meanings ascribed to it in the eyes of the students. Connotative RME decoupling sensitizes us to the importance of the meaning dimension in decoupling and institutionalization (see also the notion of "communicative institutionalism" by Cornelissen et al., 2015).

\section{Overcoming PRME Implementation Barriers}

What can be done to better align the formal and hidden RME curricula to support the implementation of PRME? Addressing this question requires us to reflect on how a business school can alter the tacit messages that students receive. Of course, we cannot provide any definite advice based on a single case study, and given the contextualized nature of higher education (e.g., influenced by national legislation) we should be wary of rushing into promoting general recipes for success. However, we believe that future discussions need to address the challenges discussed in this paper on at least two interrelated levels.

First, we need to include discussions of the $\mathrm{HC}$ in relevant institutionalized spaces where RME-related topics are debated and enforced. While PRME has more than once put this topic on the agenda (see, for example, PRME Working Group on Gender Equality, 2011 and PRME, 2015), other organizations have not picked up this topic. Although accreditation agencies like the European Foundation for Management Development (EFMD) and the Association of MBAs (AMBA) have explicitly acknowledged the need for RME, their discussions have been limited to the formal curriculum. AMBA (2016, p. 7), for instance, includes acquiring knowledge and skills on ethics as expected learning outcomes of MBA programs, but it does 
not look into the tacit messages students may receive through the HC. Also, while ranking providers such as the Financial Times have recently shown stronger support for RME (e.g., by measuring to what extent relevant topics are discussed in the core curriculum), the emphasis again is solely on what is visible in the formal curriculum, thereby neglecting the tacit messages conveyed to students as part of the HC. Of course it is not easy to measure the HC for ranking and accreditation purposes, but asking current students as well as alumni about their learning experiences of RME may be a first step to move beyond merely "counting courses".

Second, schools can look into activities that address the problems identified along the three message sites. We share Blasco's (2012) belief that it is possible to instill "PRMEfriendly attitudes and behaviors" (p. 380) in the message sites. We believe that two sets of activities deserve particular attention. On the one hand, it is important to reflect more carefully on the content and delivery of the formal curriculum. Here it is vital to go beyond discussions of whether or not topics like CSR, ethics, and sustainability are covered and in which parts of a program, since such a "tick-the-box" approach actually impedes reflection on tacit messages. Rather it is essential to nurture a dialogue among faculty about the tacit messages that could potentially be attached to different subject areas, especially those areas that are often portrayed as value-neutral (e.g., economics and finance; PRME, 2015). Such diagnostic work can only succeed through explicit and repeated discussions among faculty (Orón Semper \& Blasco, 2018). The goal should not be to shame anyone or any particular subject area but rather to encourage critical reflection among faculty about what they (not) do in the classroom and which intended and unintended messages they may be sending to students. Ultimately, reflecting on the $\mathrm{HC}$ requires that teachers reflect on themselves (e.g., their ideologies, routine practices, and assumptions). On the other hand, it is also important to reflect on whether relevant organizations actually "walk their talk". Many examples exist where schools do not (yet) practice what at least some of their faculty preach in the classroom. This relates, for 
instance, to schools' environmental practices (e.g., $\mathrm{CO}_{2}$ emissions due to travel) as well as the treatment of misconduct (e.g., dealing with plagiarism). But it is usually possible to address such inconsistencies between talk and action. For instance, following the tobacco firm sponsorship case, The School set up a multi-stakeholder council to develop guidelines regulating which companies the organization wants to partner with.

\section{CONCLUSION}

This exploratory study set out to discuss the extent to which the formal and hidden RME curricula are aligned in the context of PRME participant schools. Through a case study of one business school within the PRME community, we revealed misalignments between the messages communicated explicitly in the formal curriculum and the messages communicated more implicitly through the HC's three message sites. Our study demonstrates that the HC can potentially reduce students' sense of the value and importance of responsible management. If left unaddressed, the $\mathrm{HC}$ is likely to remain an invisible barrier preventing business schools from developing more responsible graduates. Given the increasing scale of RME (e.g., as manifest in the growth of the PRME community) and the resources schools devote to it, a discussion of how to improve the alignment between the formal and hidden RME curricula seems both important and timely.

Several directions for future research follow from our study. First, there is a need to discuss the alignment of the formal and hidden RME curricula in a comparative perspective. For instance, a comparison among PRME Champion schools (e.g., of different sizes and with different program portfolios) could show whether our observed tacit messages are applicable beyond the context of a single institution. Such research could also expose the extent to which the national context of higher education shapes students' perceptions of the HC (e.g., corporate sponsorship of lecture halls is not permitted in all countries). It would also be interesting to 
study whether perceptions of "soft" topics (e.g., ethics and CSR) change in light of recent insights about systemic (financial) risks that are attached to humanity transgressing several planetary boundaries (Whiteman, Walker, \& Perego, 2013).

Second, while our study exposed tacit messages generated in three message sites, we did not examine the extent to which these messages interact with each other. It would be interesting to study how far the lack of consistency that students identified with regard to sponsorship issues affects their perception that CSR is just a "buzzword". Finally, future research can take up our proposition to further investigate the ways in which connotative decoupling may be relevant in generating misalignments between the formal and hidden RME curricula as perceived by students. Such research needs to look into processes of meaning construction among students as well as among faculty and administrators; it has to examine how the meaning of relevant tacit messages is attached to what is said but also to what is absent and unsaid. Sometimes the absence of statements (e.g., by a lecturer during exam preparation) says more than a thousand words. 
Ethical approval: All procedures performed in studies involving human participants were in accordance with the ethical standards of the institutional and/or national research committee and with the 1964 Helsinki Declaration and its later amendments or comparable ethical standards.

Informed consent: Informed consent was obtained from all individual participants included in the study.

\section{REFERENCES}

Alcaraz, J. M., Marcinkowska, M. W., \& Thiruvattal, E. (2011). The UN-Principles for Responsible Management Education. Journal of Global Responsibility, 2(2), 151-169.

Arieli, S., Sagiv, L., \& Cohen-Shalem, E. (2016). Values in business schools: The role of self-selection and socialization. Academy of Management Learning and Education, 15(3), 493-507.

AMBA. MBA Accreditation Criteria; Available at: https://www.mbaworld.com//media/Files/Accreditation/MBA-criteria-for-accreditation.ashx?la=en

Bergenhenegouwen, G. (1987). Hidden curriculum in the university. Higher Education, $16(5), 535-543$.

Blasco, M. (2012). Aligning the hidden curriculum of management education with PRME: An inquiry-based framework. Journal of Management Education, 36(3), 364-388.

Borges, J. C., Ferreira, T. C., de Oliveira, M. S. B., Macini, N., and Caldana, A. C. F. (2017). Hidden curriculum in student organizations: Learning, practice, socialization and responsible management in a business school. The International Journal of Management Education, 15(2), 153-161.

Burchell, J., Kennedy, S., \& Murray, A. (2015). Responsible management education in UK business schools: Critically examining the role of the United Nations Principles for Responsible Management Education as a driver for change. Management Learning, 46(4), 479-497.

Cezarino, L. (2016). Teachers' opinion about sustainability on management education. Business Management Dynamics, 6(1), 1-8.

Charmaz, K. (2006). Constructing grounded theory. Sage: London.

Cicmil, S., Gough, G., \& Hills, S. (2017). Insights into responsible education for sustainable development: The case of UWE, Bristol. International Journal of Management Education, 15(2), 293-305.

Cooper, R., \& Sawaf, A. (1996). Executive EQ: Emotional intelligence in leadership and organizations. New York, NY: Grosset/Putnam.

Cornelissen, J. P., Durand, R., Fiss, P., Lammers, J., \& Vaara, E. (2015). Putting communication front and center in institutional theory and analysis. Academy of Management Review, 40(1), 10-27.

Dever, R.L., \& Mills, A.J. (2015). Are we still telling female students they can't lead? A content analysis of leadership writings and representations in organizational behavior texts. In. P.M. Flynn, K. Haynes, \& M. Kilgour (Eds.). Integrating Gender Equality into 
Business and Management Education (pp. 165-182). Sheffield, UK: Greenleaf Publishing.

Ehrensal, K. N. (2001). Training capitalism's foot soldiers: The hidden curriculum of undergraduate business education. In E. Margolis (Ed.), The hidden curriculum in higher education (pp. 97-113). New York, NY: Routledge,

Elkin, G. (1995). Socialization and MBA Programs. Journal of Management Education, 19(2), 171-189.

Escudero, M. Albareda, L., Alcaraz, J.M., Weybrecht, G., \& Csuri, M. (Eds.) (2017). Inspirational Guide for the Implementation of PRME: Placing Sustainability at the Heart of Management Education. Leeds, UK: GSE Research.

Forray, J. M., \& Leigh, J. S. A. (2012). A Primer on the Principles of Responsible Management Education: Intellectual Roots and Waves of Change. Journal of Management Education, 36(3), 295-309.

Fougère, M., Solitander, N., \& Young, S. (2014). Exploring and Exposing Values in Management Education: Problematizing Final Vocabularies in Order to Enhance Moral Imagination. Journal of Business Ethics, 120(2), 175-187.

Gair, M., \& Mullins, G. (2001). Hiding in plain sight. In E. Margolis (Ed.), The hidden curriculum in higher education (pp. 21-41). Routledge: New York, NY.

Glaser, B. G., \& Strauss, A. L. (1967). The discovery of grounded theory: Strategies for qualitative research. Chicago, IL: Adline.

Godemann, J., Haertle, J., Herzig, C., \& Moon, J. (2014). United Nations supported Principles for Responsible Management Education: purpose, progress and prospects. Journal of Cleaner Production, 62, 16-23.

Godemann, J., Herzig, C., Moon, J., \& Powell, A. (2011). Integrating Sustainability into Business Schools: Analysis of 100 UN PRME Sharing Information on Progress (SIP) reports. International Centre for Corporate Social Responsibility (ICCSR), Working Paper No. 58-2011. Nottingham: ICCSR.

Greenberg, D. N., Deets, S., Erzurumlu, S., Hunt, J., Manwaring, M., Rodgers, V., \& Swanson, E. (2017). Signing to living PRME: Learning from a journey towards responsible management education. International Journal of Management Education, $15(2), 205-218$.

Guest, G., Namey, E. E., \& Mitchell, M.L. (2013). Collecting Qualitative Data: A Field Manual for Applied Research. Thousand Oaks, CA: Sage.

Hafferty, F. W., \& Franks, R. (1994). The hidden curriculum, ethics teaching, and the structure of medical education. Academic Medicine, 69(11), 861-871.

Haski-Leventhal, D., Pournader, M., \& McKinnon, A. (2017). The Role of Gender and Age in Business Students' Values, CSR Attitudes, and Responsible Management Education: Learnings from the PRME International Survey. Journal of Business Ethics, 146(1), 219-239.

Ketokivi, M., and Mantere, S. (2010). Two strategies for inductive reasoning in organizational research. Academy of Management Review, 35(2), 315-333.

Kirby, S. L. (2012). Implementing the Principles of Responsible Management Education: Examining Understandings of Economic, Social, and Environmental Sustainability. Journal of Strategic Management Education, 8(1), 61-76. 
Kolb, M., Fröhlich, L., \& Schmidpeter, R. (2017). Implementing sustainability as the new normal: Responsible management education - From a private business school's perspective. International Journal of Management Education, 15(2), 280-292.

Kvale, S. (2011). Doing Interviews. Sage: London.

Laasch, O. \& Conaway, R.N. (2015). Principles of Responsible Management: Global Sustainability, Responsibility, and Ethics. Stamford, CA: Cengage.

Li, Y. (2017). A semiotic theory of institutionalization. Academy of Management Review, $42(3), 520-547$.

Li, J. (2008). Ethical challenges in participant observation: A reflection on ethnographic fieldwork. The Qualitative Report, 13(1), 100-115.

Louw, J. (2015). "Paradigm Change" or No Real Change At All? A Critical Reading of the U.N. Principles for Responsible Management Education. Journal of Management Education, 39(2), 184-208.

Maloni, M. J., Smith, S. D., \& Napshin, S. (2012). A methodology for building faculty support for the United Nations Principles for Responsible Management Education. Journal of Management Education, 36(3), 312-336.

Margolis, E., Soldatenko, M., Acker, S., and Gair, M. (2001). Peekaboo: Hiding and outing the curriculum. In E. Margolis (Ed.), The hidden curriculum in higher education (pp. 120). New York, NY: Routledge.

McCracken, G. (1988). The long interview. Newbury Park, CA: Sage.

Millar, J., \& Price, M. (2018). Imagining management education: A critique of the contribution of the United Nations PRME to critical reflexivity and rethinking management education. Management Learning, 49(3), 346-362.

Nhamo, S., \& Nhamo, G. (2014). Assessing progress in implementing UN PRME International perspectives and lessons from South Africa. Problems and Perspectives in Management, 12(1), 94-108.

Orón Semper, J. V., \& Blasco, M. (2018). Revealing the Hidden Curriculum in Higher Education. Studies in Philosophy and Education, 37(5), 481-498.

Ottewill, R., McKenzie, G., \& Leah, J. (2005). Integration and the hidden curriculum in business education. Education \& Training 47(2), 89-97.

Pace, J. L., \& Hemmings, A. (2007). Understanding Authority in Classrooms: A Review of Theory, Ideology, and Research. Review of Educational Research, 77(1), 4-27.

Patton, M. Q. (2015). Qualitative Research \& Evaluation Methods. Los Angeles: Sage.

Polanyi, M. (1962). Personal knowledge: Towards a post-critical philosophy. Chicago, IL: University of Chicago Press.

PRME (2015). Faculty Development for Responsible Management Education: Results from a Survey among PRME Signatories. Available: at: http://www.unprme.org/resourcedocs/FDReportFinalWeb.pdf

PRME Working Group on Gender Equality (2011). Discussion Paper. Available at: https://www.google.com/url?q=http://www.unprme.org/resourcedocs/PRMEWGGenderEqualityDiscussionPaper.docx 
Rasche, A., \& Gilbert, D. U. (2015). Decoupling responsible management education: Why business schools may not walk their talk. Journal of Management Inquiry, 24(3), 239252.

Rasche, A., Gilbert, D. U., \& Schedel, I. (2013). Cross-disciplinary ethics education in MBA programs: Rhetoric or reality? Academy of Management Learning \& Education 12(1), $71-85$.

Sambell, K., \& McDowell, L. (1998). The construction of the hidden curriculum: Messages and meanings in the assessment of student learning. Assessment and Evaluation in Higher Education, 23(4), 391-402.

Snelson-Powell, A., Grosvold, J., \& Millington, A. (2016). Business school legitimacy and the challenge of sustainability: A fuzzy set analysis of institutional decoupling. Academy of Management Learning \& Education, 15(4), 703-723.

Solitander, N., Fougere, M., Sobczak, A., \& Herlin, H. (2011). We are the champions: Organizational learning and change for responsible management education. Journal of Management Education, 36(3), 337-363.

Toner, J. (2009). Small is not too small: Reflections concerning the validity of very small focus groups (VSFGs). Qualitative Social Work, 8(2), 179-192.

Tonso, K. L. (2001). Plotting something dastardly: Hiding a gender curriculum in engineering. In E. Margolis (Ed.), The hidden curriculum in higher education (pp. 155174). New York, NY: Routledge.

Trevino, L. K., \& McCabe, D. (1994). Meta-learning about business ethics: Building honorable business school communities. Journal of Business Ethics, 13(6), 405-416.

Warin, C. \& Beddewela, E. (2016). Drivers, barriers, and enablers of institutionalizing responsible management education. In R. Sunley \& J. Leigh (Eds.) Educating for Responsible Management: Putting Theory into Practice (pp. 301-324). Sheffield, UK: Greenleaf Publishing.

Whiteman, G., Walker, B., \& Perego, P. (2013). Planetary boundaries: Ecological foundations for corporate sustainability. Journal of Management Studies, 50(2), 307336.

Young, S., \& Nagpal, S. (2013). Meeting the growing demand for sustainability-focused management education: a case study of a PRME academic institution. Higher Education Research \& Development, 32(3), 493-506. 


\section{TABLES AND FIGURES}

Table 1: Overview of analyzed study programs and focus group interviews

\begin{tabular}{|l|l|l|l|}
\hline Study Program & Acronym & $\begin{array}{l}\text { Number of } \\
\text { Focus } \\
\text { Groups }\end{array}$ & $\begin{array}{l}\text { Number of } \\
\text { Interviewees }\end{array}$ \\
\hline Bachelor program with focus on international business & BA INT & 2 & 5 \\
\hline Bachelor program with focus on business and economics & BA ECON & 1 & 2 \\
\hline Bachelor program with a focus on communication 1 & BA COM1 & 2 & 4 \\
\hline Bachelor program with a focus on communication 2 & BA COM2 & 2 & 4 \\
\hline Bachelor program with a focus on sociology & BA SOC & 1 & 4 \\
\hline Master program with a focus on communication & MA COM & 3 & 6 \\
\hline Master program with a focus on economics and finance & MA E\&F & 2 & 5 \\
\hline Mixed group from Master programs & MA COM & 1 & 2 \\
\hline Total & MA E\&F & $\mathbf{1 4}$ & $\mathbf{3 2}$ \\
\hline - Female & & & 20 \\
\hline - Male & & & 12 \\
\hline
\end{tabular}


Table 2: RME content in the formal curriculum of the analyzed study programs

\begin{tabular}{|c|c|c|c|c|c|c|c|}
\hline & BA INT & BA ECON & BA COM1 & BA COM2 & BA SOC & MA E\&F & МА COM \\
\hline Courses & $\begin{array}{l}\text { - Flagship RME: } \\
\text { Corporate } \\
\text { Governance } \\
\text { - Other Relevant } \\
\text { Courses (Selection): } \\
\text { International } \\
\text { Economics, } \\
\text { International } \\
\text { Business Strategy, } \\
\text { Industrial } \\
\text { Organizational } \\
\text { Analysis }\end{array}$ & $\begin{array}{l}\text { - Flagship RME: } \\
\text { Strategy } \\
\text { - Other Relevant } \\
\text { Courses: } \\
\text { Managerial } \\
\text { Economics, } \\
\text { Finance, } \\
\text { Microeconomics }\end{array}$ & $\begin{array}{l}\text { - Flagship RME: } \\
\text { Society Analysis } \\
\text { and Diagnostics } \\
\text { - Other Relevant } \\
\text { Courses (Selection): } \\
\text { Branding, Strategic } \\
\text { Communication, } \\
\text { Institutional } \\
\text { Perspectives }\end{array}$ & $\begin{array}{l}\text { - Flagship RME: } \\
\text { Responsible } \\
\text { Management } \\
\text { - Other Relevant } \\
\text { Courses (Selection): } \\
\text { Marketing Audit, } \\
\text { Marketing Strategy, } \\
\text { Corporate } \\
\text { Communication, } \\
\text { Communication } \\
\text { Across Cultures }\end{array}$ & $\begin{array}{l}\text { Flagship RME: } \\
\text { The Art and } \\
\text { Practices of } \\
\text { Business } \\
\text { Accounting, } \\
\text { Business, Politics } \\
\text { \& Society } \\
\text { - Other Relevant } \\
\text { Course (Selection): } \\
\text { Introduction to } \\
\text { Economic } \\
\text { Sociology, } \\
\text { Theories of } \\
\text { Contemporary } \\
\text { Society }\end{array}$ & $\begin{array}{l}\text { - Courses with } \\
\text { potential RME } \\
\text { Content: Corporate } \\
\text { Governance, } \\
\text { Corporate Finance }\end{array}$ & $\begin{array}{l}\text { Courses with RME } \\
\text { Content } \\
\text { (Selection): } \\
\text { Strategy \& } \\
\text { Communication, } \\
\text { Leadership } \\
\text { Rhetoric, } \\
\text { Corporate } \\
\text { Responsibility \& } \\
\text { Organization, } \\
\text { Corporate } \\
\text { Responsibility \& } \\
\text { Society }\end{array}$ \\
\hline $\begin{array}{l}\text { Identified } \\
\text { RME } \\
\text { Competency } \\
\text { Profile }\end{array}$ & $\begin{array}{l}\text { - Ability to act in } \\
\text { accordance with } \\
\text { accepted principles } \\
\text { of right and wrong } \\
\text { - Ability to } \\
\text { understand ethical, } \\
\text { normative, social } \\
\text { issues }\end{array}$ & $\begin{array}{l}\text { - Ability and } \\
\text { awareness to } \\
\text { identity } \\
\text { responsibility issues } \\
\text { - Ability to } \\
\text { understand dynamic } \\
\text { nature of } \\
\text { responsibility } \\
\text { - Ability to recognize } \\
\text { that responsibility } \\
\text { needs to be } \\
\text { embedded }\end{array}$ & $\begin{array}{l}\text { - Ability to } \\
\text { understand } \\
\text { challenges for } \\
\text { responsible } \\
\text { managers } \\
\text { - Ability to reflect } \\
\text { upon ethical } \\
\text { implications of } \\
\text { communication } \\
\text { - Ability to consider } \\
\text { stakeholder } \\
\text { concerns in } \\
\text { communication }\end{array}$ & $\begin{array}{l}\text { - Ability to } \\
\text { understand } \\
\text { responsibility as } \\
\text { culturally } \\
\text { contingent } \\
\text { - Ability to } \\
\text { understand } \\
\text { challenges for } \\
\text { responsible } \\
\text { communication in } \\
\text { marketing } \\
\text { - Ability to work with } \\
\text { intercultural } \\
\text { marketing from a } \\
\text { responsibility angle }\end{array}$ & $\begin{array}{l}\text { - Ability to make } \\
\text { responsible use of } \\
\text { knowledge } \\
\text { acquired through } \\
\text { theory } \\
\text { - Ability to identify } \\
\text { and take into } \\
\text { account prospects } \\
\text { and challenges for } \\
\text { a broad range of } \\
\text { societal } \\
\text { stakeholders }\end{array}$ & n.a. & n.a. \\
\hline
\end{tabular}


Table 3: Overview of tacit messages embedded in The School's hidden curriculum

\begin{tabular}{|l|l|l|}
\hline \multicolumn{1}{|c|}{ Formal Curriculum } & \multicolumn{1}{c|}{ Interpersonal Interactions } & \multicolumn{1}{c|}{ School Governance } \\
\hline $\begin{array}{l}\text { CSR perceived as a } \\
\text { "buzzword" (driven by non- } \\
\text { specific usage within courses) } \\
\text { / relevant debates are } \\
\text { perceived as "common sense' }\end{array}$ & $\begin{array}{l}\text { Lecturers: devalued "softer" } \\
\text { programs with a focus on } \\
\text { responsibility, which students } \\
\text { perceived as a lack of interest } \\
\text { in the topic of responsibility }\end{array}$ & $\begin{array}{l}\text { Students perceived mixed } \\
\text { messages, as The School } \\
\text { partnered with some firms that } \\
\text { had a poor track record in CSR } \\
\text { (e.g., tobacco industry) }\end{array}$ \\
\hline $\begin{array}{l}\text { CSR had never been a } \\
\text { prevalent theme in readings / } \\
\text { CSR is seldom an exam topic } \\
\text { (students could afford to } \\
\text { "skip it") }\end{array}$ & $\begin{array}{l}\text { Students: perception that } \\
\text { "softer" study programs would } \\
\text { not have the same value in the } \\
\text { business world as some of the } \\
\text { "harder" programs }\end{array}$ & $\begin{array}{l}\text { Students questioned the } \\
\text { seriousness of RME, as they } \\
\text { believed that The School's } \\
\text { recent hiring practices send a } \\
\text { contradictory message }\end{array}$ \\
\hline $\begin{array}{l}\text { CSR perceived as an } \\
\text { insufficiently integrated topic } \\
\text { / relevant discussions are } \\
\text { disconnected from "core" } \\
\text { subjects like finance }\end{array}$ & & \\
\hline
\end{tabular}




\section{APPENDIX 1}

\section{Interview guide for focus groups}

Our interview procedure followed an interview guide approach in which topics and issues are pre-defined while allowing the interviewer to decide on the precise wording and sequence of questions (Patton, 2015). In this way, a "rough travel itinerary" (McCracken, 1988, p. 37) is provided so that interviews can remain conversational and situational, allowing for an increase in the comprehensiveness of the data. The semi-structured character of the interview guide approach was especially suited for our purpose of conducting interviews in small focus groups, as it "keeps the interactions focused while allowing individual perspectives and experiences to emerge" (Patton 2015, p. 439).

\section{Questions related to the formal curriculum}

- Ask students to elaborate and explain RME in their own words, using free writing.

- Ask students where they have experienced topics of responsible management education in their study program (e.g. readings, exercise classes, lectures).

- Ask students where they have experienced responsible management education outside of class at The School, e.g. extracurricular activities (case competitions, student organizations, etc.).

- Ask students to rate how important they believe responsible management education is at The School, based on their experience in classes and readings on a scale from 1-10.

- Ask students about the importance of responsible management education in relation to exams.

\section{Questions related to interpersonal interactions}

- Ask students to describe the culture within their program.

- Ask students how they think future employers value responsible management competencies when hiring.

- Ask students about lecturers and guest lecturers and how they have experienced these lecturers dealing with responsible management education.

\section{Questions related to school governance}

- Ask students how they experience The School's governance and practices in relation to responsible management education.

- Ask students if they can provide examples of where The School as an organization engages in responsible management.

- Ask students if they can provide examples of where The School as an organization can improve its engagement in responsible management.

- Ask students about the physical environment of The School in relation to responsibility and sustainability efforts. 


\section{APPENDIX 2}

\section{Data structure underlying the exploratory study}

$\begin{array}{ll}\text { Key } & \text { Dominant } \\ \text { Categories } & \text { Themes }\end{array}$

Formal CSR as

\section{Curriculum buzzword}

"[CSR] it is sort of superficial. It is chapter 14 that we read in the last lecture. I feel like it has become a [The School] thing."

Group

/Observation

BA INT

"I think CSR has also become this buzzword that communications people like to talk about. But I think it's really just about common sense. We don't really need classes on CSR to know that we have to act responsibly. CSR was mentioned a couple of times on our bachelor, but it was just superficial. And in our readings, sometimes CSR was mentioned, but it was almost always this chapter in the back of the book, and I think most of us usually just skipped it, because it wasn't very relevant."

"It's more becoming like a buzzword that 'Oh we need to have a CSR strategy!' because people will think well of you. Instead of actually focusing on the problems that CSR can solve. I think it's a bit problematic that it's just becoming a buzzword, and something that you need to have because it's nice rather than actually trying to do something good."

“CSR appeared as this superficial buzzword you didn't know what to do about [...] it was mentioned over and over again, but we didn't really go into depth."

"CSR, it's a concept that everyone talks about now, you know, there is a buzz around it. And because no one really knows what it means, like CSR where there are a million definitions, people can twist it to whatever purpose they have. And at some point the concept is not very useful anymore because it's been washed out and a new concept replaces it."

CSR as a

"Our teachers didn't really go into depth with it and it wasn't something they would test us on in the exam."

non-

compulsory

reading and

exam topic

"As [...] already mentioned, it is sort of superficial. It is chapter 14 that we read in the last lecture."

"[...] in our readings, sometimes CSR was mentioned, but it was almost always this chapter in the back of the book, and I think most of us usually just skipped it because it wasn't very relevant."

"We had it in a first-year project, where we used it with the isms and the institutional development of CSR, which we applied it to. But that was because we thought the case was up to it, but we were not forced to know it in any exam."
MA E\&F

BA INT

MA E\&F

\section{BA INT}

MA COM

MA COM

MA E\&F

BA COM1 
CSR as a

non-

integrated

topic with

doubtful

practical

relevance

and

applicability
"I asked the student I was sitting next to if he could describe how he understood value creation to me. He almost mirrored the teacher's words. I asked him if he could think of other ways to consider the value creation of a company, but he could not. I asked him about the value that a corporation for example brings to society and he seemed a bit surprised by this question. I asked him why he reacted like that. He just shook his head and said that of course corporations were important to society, but his job was not to consider this. He had to focus on the interests of the shareholders, which almost always meant value creation in terms of profit optimization."

"What is important when you are sitting at a job interview or somebody is asking you what can you actually do in terms of CSR and I am like I know what it is [...] but how can you actually implement it, what is the impact that you can make here, and we are not learning that, so it is not going to help me just knowing what it is. I know I am surrounded by it, but I have no idea how to do it in practice. So [The School] is not gonna help me in that sense. Not at all."

"I think we have competed in most of the case competitions during our time at [The School], but we never touch upon CSR. It's usually a big challenge which the organization is facing that is the focus and to be honest, I don't think CSR is ever one of them."

"I left because it was so bad. It didn't seem relevant at all, because [the guest lecturer] didn't put it into any relevant context. People in class were laughing about it afterwards. CSR mainly appeared as a joke."

"We were never discussing CSR strategies or how to apply them. I never knew how to operationalize the word."

"When I'm doing these CSR activities at work, it's almost expected of me to account for whether or not we're making money on them. I don't have a methodology on that which makes it very difficult. I would really like to get some help from the marketing or finance department, but nobody knows shit about it. So I don't feel I can apply much of the CSR knowledge I have to what I do. It's not really useful."

\section{Interpersonal Lecturer- Interactions student}

"Someone told me they were in the IB class, and the teacher came in, and there was another program also participating, from shipping and trade, and then the lecturer came in and said "I'm so honored to be teaching IB students" - completely neglecting the other group. But it shows I guess, that reputation is a part I would say."

"The last part of the class seemed very difficult content-wise, but none of the students raised their hands to ask questions. The teacher kept asking if they had understood the material, but no one ever replied. At one point, the teacher pointed a finger at one of the students and said: "It seems like that girl up there with the coffee cup didn't get it so I'm going to explain it again for her". She blushed 
completely and sank deeper into her chair. After the class, I asked one of the other students if she had understood everything. No, she had not. But why did she not ask any questions then? Why did not anyone ask questions? She said that people just did not want to seem stupid. She did not want to be the slow girl."

"When we had a course on economics, our teacher said something like: "We're doing the easy version, so it's not too difficult for you, since you're only studying communications."

"Recently, I defended my masters thesis. It was a horrible paper, I knew that, and of course my supervisor commented on it. He said that the work on the analysis was pretty weak, but that was probably because I studied [the program]. He was like: "What can you expect?" I got really mad, especially since I had just finished my masters degree, and there he told me that it was almost useless. Like: "Congratulations, but this is horrible."."

"The problem, maybe challenge with $\mathrm{PhD}$ students teaching is that they don't have any real world experiences. So the problem is just that in order to teach how to be a responsible manager in real life... shouldn't you be a manager at some point? [...] they learn all these theories and then they go on and have their masters and more theories and then they have their PhD and a project on these theories. And then, they teach. The theories again. And then you don't get this real life 'how to be an actual responsible manager'. Because they don't know."

Studentstudent interactions
"When I was first accepted to [The School], friends of mine who already studied at [The School], mocked me and said I had been accepted to the soft and easy program. And I get the feeling this is sort of the general perception at [The School]."

"When I talked to my boyfriend who studies one of those programs that [The School] just loves, [...] they were being taken out to different companies, had consultants coming to tell them about their opportunities, and it was just so obvious that the priorities of [The School] was reflected in the different treatment between the programs. And we were not as important as the others. [...][the program], for example, they get a graduation ceremony which [the other program] doesn't. And on my bachelor, I had no clue that we had the opportunity to compete in case competitions and travel the world with a case team, because they never told us. [The School] is sort of recruiting only [the program] students and similar programs."

"I have a friend who studies communications and she seems pretty passionate about CSR, although I always mock her about it. But I just don't have the same interest in it as she does."

"I think we have one of the harder programs. I mean, we usually joke about the communications or language students. I think you can always learn to communicate and you don't need a whole degree in that."

"The students were unsure about what I meant regarding their professional identities, but one of them eventually laughed and said: "Well we are the more laid-back students, alright! We are the slackers" [...] She explained that she did not see herself necessarily as a lazy student, but she had often experienced friends from other study programs making fun of her and her fellow students from CMK
MA E\&F

MA E\&F

BA SOC

\section{MA COM}

MA COM

MA E\&F

MA E\&F

MA COM

Observation 
because they studied something that was not very prestigious. [...] she said, that communications was not among the hard programs and they did not feel as important as some of the other programs. The "other" programs she was referring to, she described as "the more hardcore programs, like Finance".

"I feel like we downgrade ourselves a bit. Because we are a soft science here at [The School], compared to [the other programs]."

\section{School}

\section{Governance}

Sponsorships "Yes, I think it is more on a like symbolic level. It is not because they change to punish [the bank] that they can't collaborate, it is more just because, well people don't think it is ok, so we won't do it. I think it is a bit weak."

"It is really nice when you do it and then it just gets cold. I mean also we students, we are never gonna drop [the bank], it is just such a quick and stupid decision in some way. I guess why [The School] would want to do it. They are a global frontrunner in some sense in CSR and responsible management education but then c'mon lets learn from it. And not just work with the media in sort of a PR approach, let's do it in a proper way and do it for the students instead of doing it for us as an organization, I mean as students we don't care about PR, for real, maybe some students do, I guess I don't even know why we do, but I think, it just seems political instead of... it feels stupid."

"I think it has been quite reactive so far. Because they had all these collaborations, let's say with the [tobacco firm], where they only reacted when people started to ask "Hey, why are you collaborating with them?" and then ended the partnership. I don't know..."

"[The banker] would be the example gathering all the negative corporate ideas, right. And you can actually do that and be successful.. Not necessarily what he is saying, but also what he represents, too."

"I think it is a big risk, if a student a student later on also makes a scandal and he says I got this teacher and he taught me that... I think it could be a risk..."

"But if [the banker] is able to be a professor like to talk about mistakes, and talk about what he did and like incorporate that in his lectures and his studies, that would be a great opportunity. But that depends on how the cooperation is between [The School] and him."

"Yeah, plus [The School], like why do people come to [The School]? People come to [The School] because they want to see PhD students doing his thesis on Instagram? ... I don't think so." (laughing) 